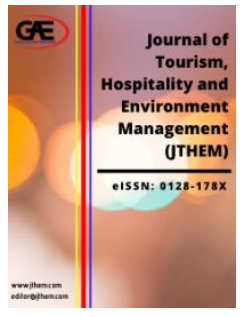

\author{
JOURNAL OF TOURISM, \\ HOSPITALITY AND \\ ENVIRONMENT MANAGEMENT \\ (JTHEM) \\ www.jthem.com
}

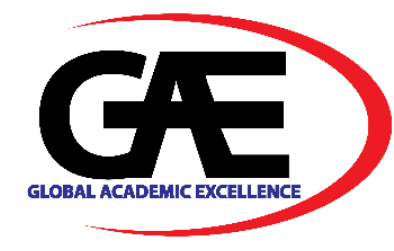

\title{
A STUDY OF URBAN MORPHOLOGY AND URBAN DESIGN ELEMENTS: PEKAN REMBAU, NEGERI SEMBILAN
}

\author{
Siti Nabila Mokhtar ${ }^{*}$, Noor Aimran Samsudin ${ }^{2}$ \\ 1 Department of Urban and Regional Planning, Universiti Teknologi Malaysia, Johor Bahru, Malaysia \\ Email: nabilamokhtar836@gmail.com \\ 2 Department of Urban and Regional Planning, Universiti Teknologi Malaysia, Johor Bahru, Malaysia \\ Email: nooraimran@utm.my \\ Corresponding Author
}

\section{Article Info:}

Article history:

Received date: 01.10 .2021

Revised date: 01.11.2021

Accepted date: 15.11.2021

Published date: 01.12.2021

\section{To cite this document:}

Mokhtar, S. N., \& Samsudin. N. A. (2021). A Study of Urban Morphology and Urban Design Elements: Pekan Rembau Journal of Tourism Hospitality and Environment Management, 6 (26), 262-273.

DOI: $10.35631 /$ JTHEM.626024.

This work is licensed under $\mathrm{CC}$ BY 4.0

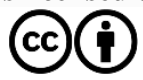

\begin{abstract}
:
Urban design is part of the planning process that covers aspects of the physical quality of the environment and urban development relationships. Urban design is formed gradually along with the development of an area. Meanwhile, urban morphology is the expansion and shape of urban change, structure, and function of a city's fabric. Therefore, the purpose of this study conducted is to overview the urban morphology pattern and to determine the urban design elements that are being implemented in the Pekan Rembau. This study is conducted to identify the pattern of urban morphology and all the elements of urban design. The methodology applied for this paper is exploratory research in Rembau District, which consists of field observation and case study or field research of urban design and morphology toward creating sustainable development has been identified. The findings of this study are the urban morphology of Rembau City centre pattern as linear patterns were successfully built as planned to reveal their various functions. Then, according to Lynch's theories of urban design elements, Pekan Rembau has identified five urban design elements. It locates urban morphology and urban design as products and processes within a framework based on the distinction between a few elements of urban. The paper concludes with suggestions of potential development and strategies.
\end{abstract}

Keywords:

Urban Morphology, Urban Design, Urban Development 


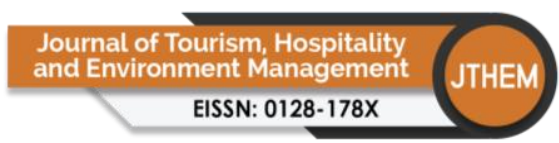

Volume 6 Issue 26 (December 2021) PP. 262-273

DOI 10/35631/JTHEM.626024

\section{Introduction}

Every city in Malaysia has a variety of history and heritage that makes this city look unique and become an identity to the country. The planning of a city must be focusing on the making of spatial order (Hall, 2014). It is believed to be a unique form of urban planning as it focuses on spatial plans and their application. The urban morphology approach is one of the heuristic ways to identify the characters and evaluate the changes that occur in the shape, spatial patterns, and functions of a city. According to Hamid (2000), Katiman Rostam (2001), Hofmiester (2003), Wall \& Waterman (2009), Alireza A. R. \& Mehrdad M. (2015), Puteri Shireen et. al (2019) state that the urban morphology can be defined as a change of development that occurs in urban design in terms of land use patterns, the direction of travel, road shape, and buildingblock shape for a city. An important aspect that needs to be highlighted in studying urban morphology is the development patterns in urban morphology. Katiman (2001) found that there are a few patterns of urban morphology in their study which is compact/solid shaped city, linear-shaped city; fragmented shaped cities; composite shaped cities; and star-shaped city. This can be achieved by looking at changes and innovations in theories, concepts and in the study of urban morphology.

Therefore, urban design is a subfield of urban planning particularly concerned with urban form, livability and aesthetics (Gunder, 2011). Urban design involves the arrangement and design of buildings, public spaces, transport systems, services, and amenities. The urban design also about making connections between people and places, movement and urban form, nature, and the built fabric. Çalışkan and Marshall (2011) state that urban design draws together with placemaking, environmental, social equity, and economic viability into the creation of places with distinct beauty and identity. Moreover, urban design is the process of giving form, shape, and character to groups of buildings, to whole neighbourhoods, and to a city. It is a framework that orders the elements into a network of streets, squares, and blocks.

Urban design blends architecture, landscape architecture, and city planning together to make urban areas functional and attractive. It draws together to create a vision for an urban area and then deploys the resources and skills needed to bring the vision to life. Kevin Lynch theory (1960) has introduced the 5 urban design elements which include:

Table 1: Five Urban Design Elements of Kevin Lynch Theory (1960)

\begin{tabular}{|l|l|}
\hline 1. Paths & $\begin{array}{l}\text { The passages that experience from the people moves: walkways, streets, } \\
\text { transit line, railroads etc. }\end{array}$ \\
\hline 2. Edges & $\begin{array}{l}\text { The boundaries that separate the continuity which is not use as paths: shores, } \\
\text { railroad cuts, edges of development, etc }\end{array}$ \\
\hline 3. Districts & $\begin{array}{l}\text { The medium-to-large sections of the city as having some common, } \\
\text { identifying character }\end{array}$ \\
\hline 4. Nodes & Point of the strategic and important spot \\
\hline 5.Landmarks & $\begin{array}{l}\text { Another type of point-reference such a physical object: sign, mountain, store, } \\
\text { or building. }\end{array}$ \\
\hline
\end{tabular}

Source: Kevin Lynch theory (1960) 
Nevertheless, the existence of various morphological analysis approaches that focus on the same assessment subject as well as the lack of integration between the approaches has affected the effectiveness from the point of view of its application. Neglect of urban design and layout creates confusion over the continuity of urban fabric.

Therefore, the purpose of this study conducted is to overview the urban morphology condition and to determine how the urban design elements are being implemented in the Rembau District.

\section{Methodology}

This paper applied exploratory research, which is consist of field observation and case study or field research of existing development pattern of urban morphology and all elements of urban design has been identified. At the first stage, the urban morphology and urban design are explained by reviewing various journal papers publications, books and government official reports or documents.

Then, the selected study area has been observed. Guided by using a checklist, few elements of the urban design of the town such as the existing condition of the town, building profile, identity and image of the town, town activities have been recorded. The changes of land use patterns such as industrial, commercial, housing, agriculture, institutions, facilities, recreation, and vacant land for Pekan Rembau will determine the pattern of urban morphology on improving urban design elements through time.

\section{Study Area}

Pekan Rembau which has the status of Main Settlement Center is the most important centre in Rembau District, Negeri Sembilan, Malaysia. Development of Pekan Rembau, focusing on administrative hubs and heritage towns in the Rembau District. The field study found that only Pekan Rembau has relatively specialized municipal activities that are focused on businesses where there are shop buildings, shop houses, and office shops. Rembau settlement centre is also supported by the population of surrounding settlement centres such as $\mathrm{Kg}$. Senama, $\mathrm{Kg}$. Ulu Chuai, Taman Seri Rembau and Taman Rembau Utama. The dominant population in the Chembong area is also to some extent supportive of activities and services in Pekan Rembau due to its close location.

Pekan Rembau is divided into 2 parts and separated by Jalan Persekutuan Seremban-Tampin. The town area located in the western part of Pekan Rembau has several business activities and there are several recreational areas and public focus. The second area is located east of Pekan Rembau. The area is more focused on the administrative area of Rembau District. The division includes administration buildings and several business buildings. There are several housing estates in the area. 


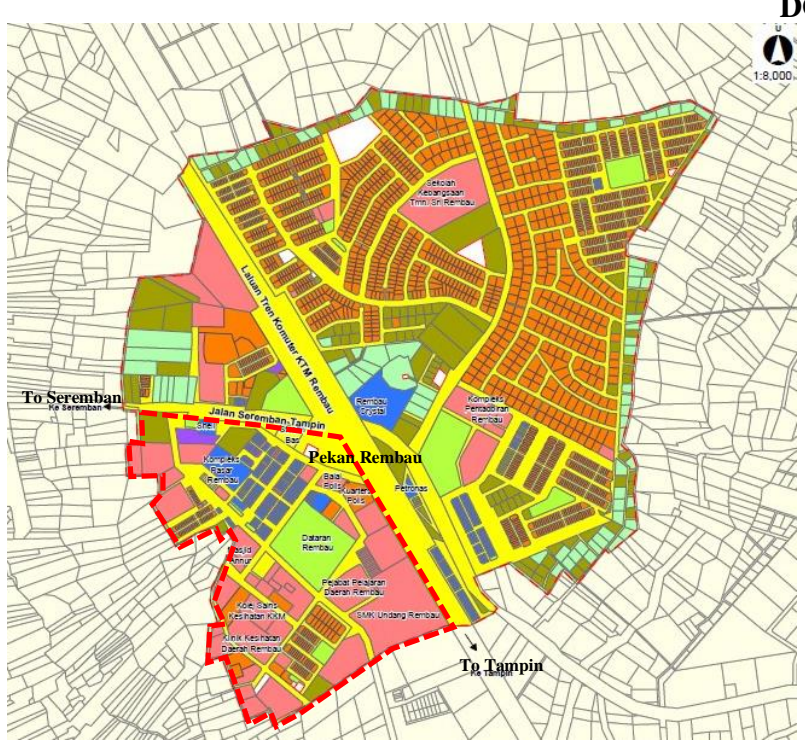

DOI 10/35631/JTHEM.626024

Figure 1: Map of Pekan Rembau, Negeri Sembilan

Source: Edited from Rembau District and Land Office

\section{Findings}

The results found at least 5 major findings on the overview of urban morphology and the elements of urban design implemented in the Pekan Rembau. This article is an overview of the urban morphology and urban design elements in Pekan Rembau with the aim to improve its quality by changing the physical condition to a vibrant and exciting urban area. The improvement of urban setting and atmosphere will enhance and attract more services, businesses, and industries to come in. Indirectly it will create more job opportunities for residents, enhance big scale business and service activities as well as create a complete urban structure.

Based on the observation and field study conducted in Pekan Rembau, the pattern of urban morphology and urban design elements can be identified. Here is the observation and findings of an overview of urban morphology and urban design elements in Rembau District, Negeri Sembilan.

\section{Existing Condition Analysis}

\section{Urban Morphology Pattern}

The development in the Rembau District area has undergone significant changes, especially for the main settlements. The developments change the hierarchy of settlements and activities as well as services in Pekan Rembau. This change is due to its location. The position of Pekan Rembau, Pekan Chembong and Pekan Pedas are parallel along the Serembau-Tampin federal road. It is also known as the Linear Development Corridor area. Based on observation and study, Pekan Rembau grows and develops with linear pattern urban morphology which is development lined up next to main roads or intersections such as Jalan Terentang, Jalan Dato 'Undang, and Jalan Dato Sedia Raja-Pulau Mampat.

The focal points in Pekan Rembau are Dataran Rembau, Pasar Besar Rembau, Masjid Jamek Annur and Rembau Bus Station. These places are a space for people to carry out various activities that can make Pekan Rembau more vibrant. The Main Settlement Center in Rembau District include 3 main towns, namely Pekan Rembau, Pekan Pedas and Pekan Chembong that 
have been given more attention to provide adequate services to the surrounding residents. The development of Pekan Rembau focuses on new administrative centers, key growth centers and potential areas to promote value-added economic growth in an integrated manner and function as growth centers for Rembau District in particular. Pekan Rembau settlement center is also supported by the population of settlement centers around the Main Settlement Center such as Kg. Batu Hampar, Kg. Chembong A and Kg. Spicy Gaing. Finally, the trend and shape of the Main Settlement Center is based on a linear concept along the main road.

Pekan Rembau includes several rows of historical buildings as well as several building blocks that have been refurbished and repaired. In addition, the town is equipped with business activities as well as several residences around it. The land use of Pekan Rembau includes government institutions, businesses, residences, main facilities, and amenities. The urban elements found in this area are the historic city, soft and rugged landscape.

Most of the activities in the Pekan Rembau area are business and retail include grocery stores, food, and beverage stalls and service activities includes clinics, banks, and workshops. The accommodation of the population of the institutions will also definitely have a positive impact on the development of activities in the central area of the settlement. The location of Pekan Rembau which is in the Linear Development Corridor and is in line with the main road is a positive feature.

This is because the Federal Road Seremban-Tampin which is accessed by Bandar Seremban supports the overflow and economic relationship of industry and business between the 2 cities which are Pekan Rembau and Seremban is within approximately $26.6 \mathrm{~km}$ only, while $34.7 \mathrm{~km}$ via PLUS Highway.

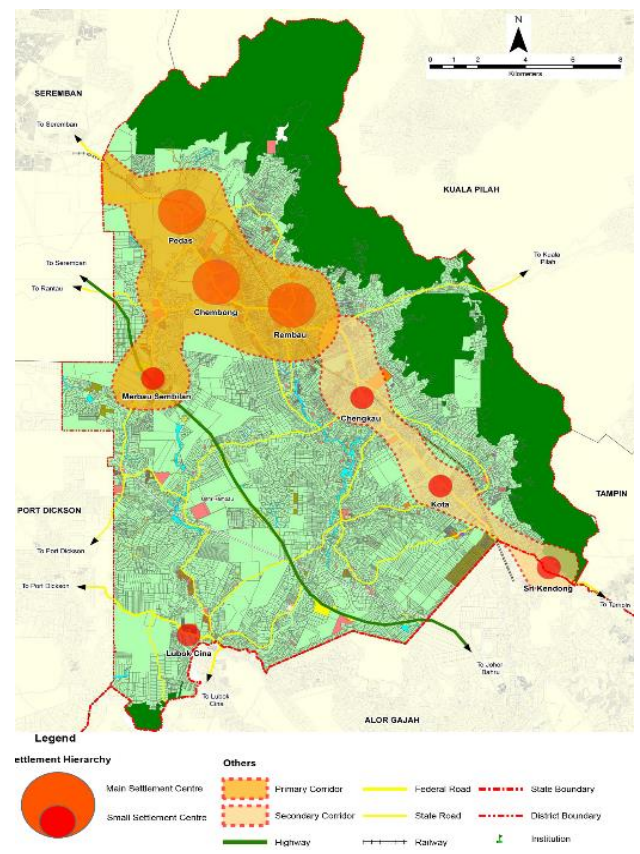

Figure 2: The Position of Pekan Rembau, Pekan Chembong and Pekan Pedas are Parallel Along the Seremban-Tampin

Source: Edited from Rembau District and Land Office 


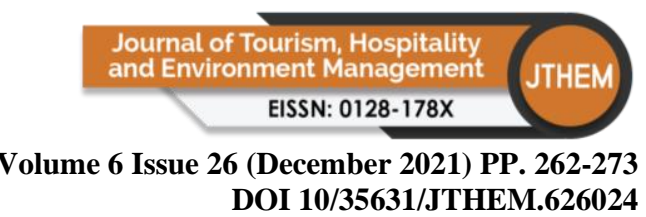

Building Profile

DOI 10/35631/JTHEM.626024

\section{Building Height}

Pekan Rembau has the highest unit of shophouses among the small towns that support the development of Rembau District which is 132 units. About $47 \%$ are units that have historical value and require a detailed conservation process, which is concentrated in Jalan Dato Undang, Jalan Terentang and Jalan Dato 'Sedia Raja-Pulau Mampat.

The average height of the building is 2 to 3 storeys. In general, the height of buildings in the Rembau area faces the problem of significant differences in the height of buildings. The floor difference between the adjoining buildings is one to two storeys. The difference in building height gives a negative view quality to the city centre.

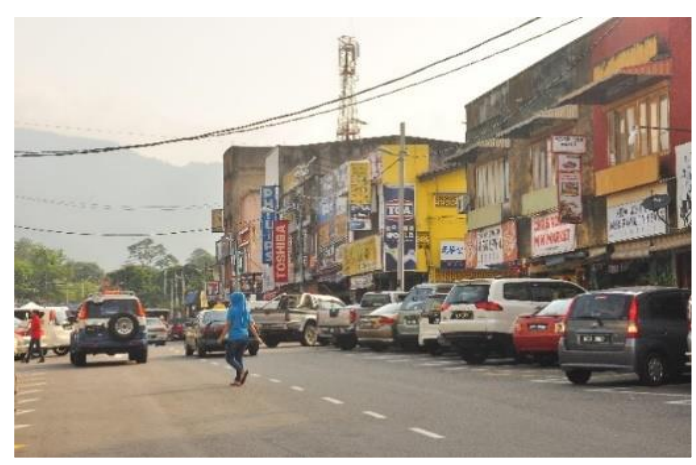

Figure 3: Building height condition in Pekan Rembau

Source: Site Survey at Pekan Rembau

\section{Building Facade}

In general, the facade is the front of a building. In architectural words, it means the appearance of the front of the most prominent building. The diversity of architectural styles of buildings plays an important role in shaping the image of the city itself. Most of the building facades in the Pekan Rembau area are in poor condition and unattractive, thus impairing the visual quality of the building. The problem is due to paint maintenance that is not carried out by the shop owner within a certain period.

The placement of oversized billboards has protected the uniqueness of the building's attractive facade and affected the heritage image of the old buildings. In the downtown area, there is non -uniform use of billboards in terms of size, placement and materials used. The non-uniformity of billboards has a negative impact on the quality of view of the style of old buildings. 


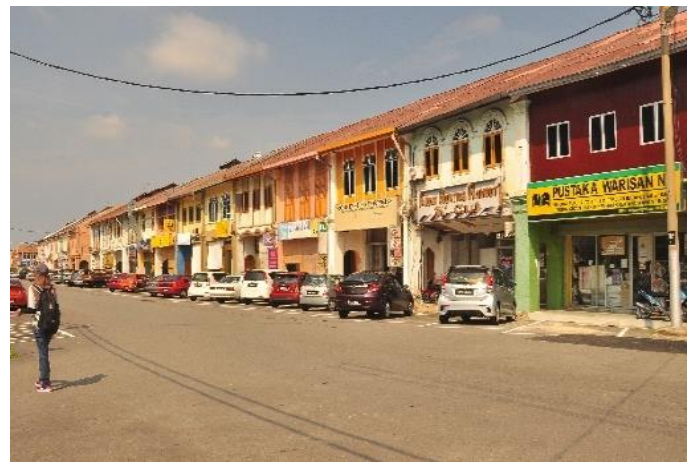

DOI 10/35631/JTHEM.626024

\section{Figure 4: Building facade condition in Pekan Rembau}

Source: Site Survey at Pekan Rembau

\section{Building Structure}

Most of the buildings in Pekan Rembau are in poor condition. This has a negative impact on development because the buildings are not safe to use in a certain period. There are buildings that have a historical value that is not preserved and maintained well especially private buildings due to lack of provisions. Not only that, but the buildings also suffered damage due to a lack of public awareness on maintenance of the buildings. Low maintenance costs are required due to the structural strength of old buildings.

The facade and structure of a shop building in Pekan Rembau have traditional and modern architecture. The buildings in Pekan Rembau have the potential to be developed to preserve heritage in the future. However, there are also some buildings that are not well maintained causing the facade and design to deteriorate and become less attractive thus affecting the image of the city of Rembau.

\section{Urban Design Elements Analysis}

The image of the city is an important aspect for people's remembrance and understanding of the special elements of the city centre whether it is space or specific activities. The image of the city is also seen as a mechanism of the human relationship with its environment. The analysis in evaluating the urban design elements of Pekan Rembau by following Kevin Lynch theory (1960) includes paths, edges, districts, nodes, and landmarks. There are the urban design elements identifies in Pekan Rembau are as follows:

\section{Path}

Pekan Rembau has several two-way routes, and most of the routes there are one-way routes. Traffic congestion is rare in Pekan Rembau due to the orderly circulation of the road. Pekan Rembau has several potential route locations and is used as a enlace between areas where most of the usage time is used by pedestrians and non -motorized vehicles. Paths elements that identify in Pekan Rembau are in Jalan Terentang, Jalan Dato Undang, Jalan Dato Abdullah, and Jalan Dato Sedia Raja-Pulau Mampat. 

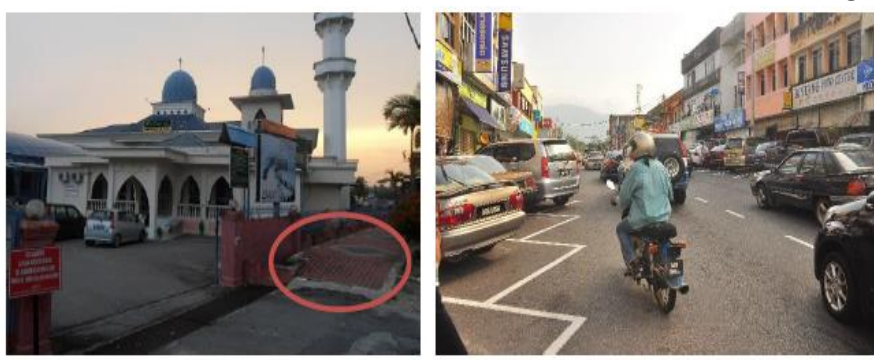

DOI 10/35631/JTHEM.626024

Figure 5: Pedestrian Walkaway Infront Masjid Annur And One-Way Routes At Jalan Terentang

Source: Site Survey at Pekan Rembau

\section{Edges}

Edges are the boundaries that separate the continuity, which is not used as paths such as shores, railroad cuts, edges of the development. The edges identified in the Pekan Rembau area is that are divided into 2 parts and separated by Jalan Persekutuan Seremban-Tampin.

\section{Districts}

Districts elements is the medium-to-large sections of the city as having some common, identifying character. The district element identifies in Pekan Rembau it has the development focus corridor of Rembau District along the Seremban-Tampin federal route and the PedasLinggi exit route, Rembau Administrative Area and Planned housing area.

\section{Nodes}

The node elements identify in Pekan Rembau is a Kompleks Pasar Rembau identity element is considered a successful node because it has linked its activities with the activities around it. Apart from that, Dataran Rembau is also one of the elements of the node in that area which has regularly runs public activities, at the village, state, national and international levels. Besides, Masjid Jamek Annur is the main mosque for the Pekan Rembau area. It is also a gathering point for Muslim people in Pekan Rembau.
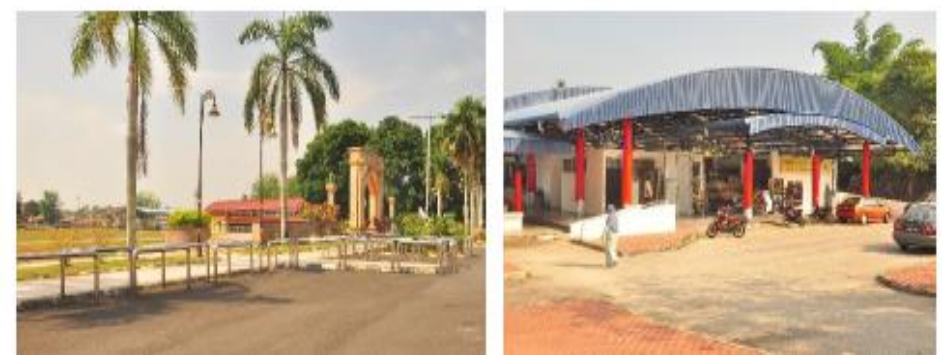

\section{Figure 6: Node Elements in Pekan Rembau include Dataran Rembau and Kompleks Pasar Rembau}

Source: Site Survey at Pekan Rembau

\section{Landmarks}

The landmark identity of Pekan Rembau identified is the sculpture of traditional musical instruments, which is located at the entrance to Pekan Rembau. The strategic position and sculptures placed high on the rocks attract the view and give clues about the area. Musical instruments consisting of gongs, drums and chaklempong mark the main road junction in the 


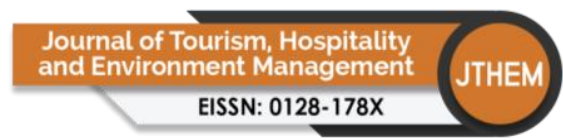

Volume 6 Issue 26 (December 2021) PP. 262-273

DOI 10/35631/JTHEM.626024

Pekan Rembau area. However, the identity of this element cannot be enjoyed by people in a comfortable and safe space because the monument is in the middle of the street.

Apart from that, Masjid Jamek Annur is also a landmark. It is seen in terms of location, consumption, and specific religious activities. Kentucky Fried Chicken (KFC), the only fastfood restaurant in Rembau is a landmark and one a meeting point of the population.

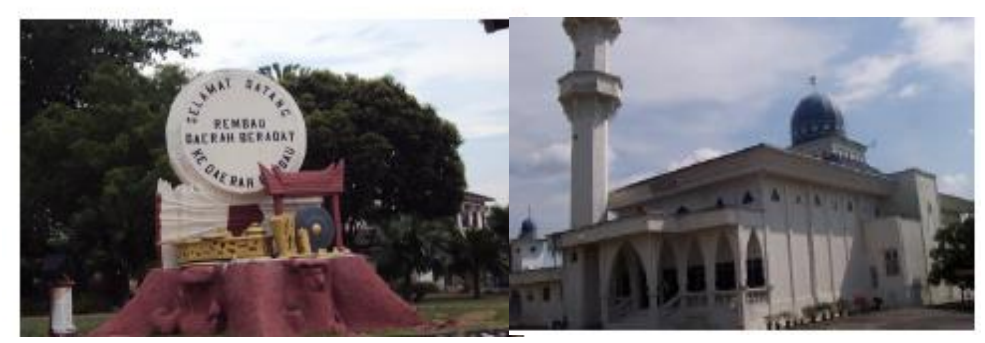

\section{Figure 7: Landmark Elements in Pekan Rembau Include the Sculpture of Traditional Musical Instruments and Masjid Jamek Annur}

Source: Site Survey at Pekan Rembau

\section{Formal and Informal Activities of the City Center Analysis}

The image of the city in the context of human activity is as complementing the suggestion about the image. Images not only depend on static entities (permanent and immobile), in fact, most of the images of certain cities are related to non-static entities (moving) human activities. Pekan Rembau, most of the residents carry out formal activities, namely business and services. There are also informal activities, such as sports that are always carried out in Dataran Rembau and others. Among the human activities that boosted Rembau's name even at the international level is Le Tour De Langkawi.

\section{Landscape Existing Condition Analysis}

Based on observation conducted, the soft and rugged landscape around the Pekan Rembau is in good condition. However, not many landscape elements are provided around the town area. Most of the landscape is shrubs and is only concentrated in the squares, mosques, and some main roads. This causes the condition of the urban environment to be less attractive, looking gloomy and hot without shade.

There are 2 main entrances to Pekan Rembau and one of the routes is sculpted as a rugged landscape and it is an indication of the area and as the identity of Pekan Rembau. Street lighting is provided as a convenience and as an attractive and unique rugged landscape. Based on the observations that have been made, it is seen that streetlights are provided around Pekan Rembau at every appropriate and orderly angle.

Soft landscapes are plants grown around the city centre. The soft landscape serves as an attraction to the study area while providing balance to the environment. Some large plants as shade during hot weather or when it rains, especially to pedestrians in the area. However, the number of landscaping plants in the Pekan Rembau area needs to be further increased.

Proposed improvements of landscaping elements and safety features are very necessary for pedestrian use. Overall, the quality of the landscape along Jalan Terentang, Jalan Dato 'Undang, 


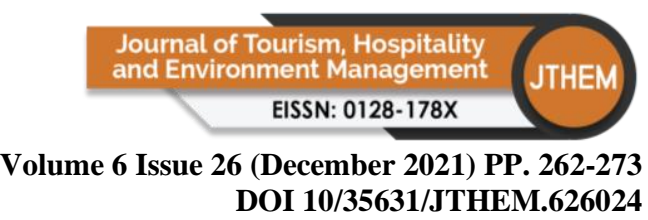

Jalan Dato Sedia Raja as well as the landscape in the Rembau administrative centre is quite good but not comprehensive.

\section{Town Circulation}

The modes of transportation in the city centre are vehicles and walking. The road communication system around Pekan Rembau is Jalan Persekutuan Seremban-Tampin, Jalan Dato 'Undang, Jalan Dato Sedia Raja, Jalan Terentang and Jalan Dato' Maharaja Lela. The intermittent pedestrian walkway system throughout the city centre reduces the accessibility of people walking to a particular location as well as giving them the inconvenience to move smoothly. The current situation in Pekan Rembau is vehicle-friendly because people are willing to drive from one location to another in the city centre even within $500 \mathrm{~m}$. Occasional congestion occurs especially on Jalan Terentang which has several rows of shops facing between the shops.

Through the main entrance to Jalan Dato Undang, the Pekan Rembau area is quite difficult for drivers, especially drivers from Chembong and Seremban. There are a few points of conflict at the main entrance of Pekan Rembau. The driver's ability to access the area's shops was also somewhat disrupted. This issue has caused the low level of visibility of business and service activities to reduce the function of certain activities in the Pekan Rembau area.

\section{Potential Development and Strategies}

The Main Settlement Center consists of 3 areas consist of Pekan Rembau, Pedas, Chembong, while the Small Settlement Center consists of Lubok China, Merbau Sembilan, Kota, Chengkau and Sri Kendong. Based on the analysis and field studies that have been carried out, several potentials have been identified.

Firstly, the locations of major growth centres are close to each other and have the potential to be developed as linear developments. The locations of the main growth centres, namely Pekan Pedas, Pekan Chembong and Pekan Rembau are close to each other and have the potential to be combined to become a linear strategic growth mode urban development. Moreover, settlement patterns are concentrated and parallel to the communication system. Most of the settlement areas are located close to linear development routes and close to growth centres. Residents can easily access the downtown area to get goods or services.

However, the overflow of development progress in the surrounding area provides the potential to promote major growth in Rembau District. Major growth such as Pekan Pedas received an overflow of development progress from the rapidly growing Senawang. This gives Pekan Pedas the potential to also grow economically and increase employment opportunities for the people in the area. In addition, small growths such as Lubok Cina Negeri Sembilan have the potential to thrive from the overflow of economic development of the border áreas.

Lastly, the small settlement centre has the potential to be developed due to its location near the entrance and exit route to Rembau District. Small settlement centres located near the entrances and exits of Rembau District have great potential for development. It is to attract outsiders to use these routes as an alternative to get to their destination and also to get to the Rembau area as well. Among the small settlement areas that have the potential to be further developed are Merbau Sembilan (Pedas-Linggi Exit, North-South Highway), Lubok China (Serusa-Lubok China Route), and Sri Kendong (Seremban-Tampin Federal Route). 


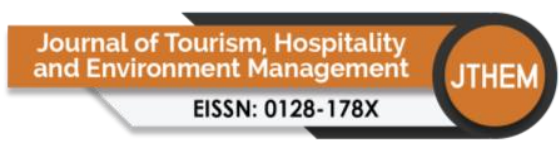

Volume 6 Issue 26 (December 2021) PP. 262-273

DOI 10/35631/JTHEM.626024

\section{Conclusion}

In conclusion, according to Lynch's theories of urban design elements, in Rembau city centre have identified five urban design elements that act as the public attraction that creates a mental image and unique visual reference points in urban space include paths, edges, districts, nodes and landmarks. The urban morphology of Rembau City centre pattern as linear patterns successfully built as planned to reveal their various functions from the urban design elements for the residents and communities.

The development of towns needs to be more focused on enhancing the elements of urban design. It can increase the income and quality of life of people that still favour their lives. In addition, the development will encourage the sellers in selecting small towns to carry out business activities due to the many advantages found in the town including occupied enough facilities, infrastructure and many more. Transformation in urban development is really needed to make the urban areas attractive, developed and at the same time will lead to national and community development.

\section{Acknowledgement}

I would like to express my special thanks of gratitude to my lecturer Dr Noor Aimran Samsudin gave me the golden opportunity to do this wonderful study and research on this topic and provide invaluable guidance throughout this research. Thank you also for UDE because sponsor the fee for this paper.

\section{References}

Alireza Arsiya Ravari and Mehrdad Mazloomi. (2015). A Framework for Urban Morpology with Respect to the Form. Armanshahr Architecture \& Urban Development, 8(14), 91103.

Gunder, M. (2011) Commentary: is urban design still urban planning? An exploration and response. Journal of Planning Education and Research, 20(10), pp. 1-12.

Hall, Peter. (2014). Cities of Tomorrow: An Intellectual History of Urban Planning and Design Since 1880. 4th Ed. West Sussex: Blackwell Publishing.

Hamid Saad, 2000. Ciri-ciri dan peranan bandar kecil dalam pembangunan wilayah: Kajian di Wilayah Johor Timur. Tesis Doktor Falsafah, Fakulti Sains Sosial dan Kemanusiaan, Universiti Kebangsaan Malaysia

Hofmeister, B. (2004). The Study of Urban Form in Germany. Urban Morphology, 8(1), 3-12. Jabatan Perancangan Bandar dan Desa, . Rancangan Struktur Negeri Sembilan 2045.

Katiman Rostam 2001, Dasar dan strategi petempatan dalam pembangunan negara. Bangi: Penerbit UKM.

Khashim, N. F., Ismail, M., Hassan, A.S. and Al-Ashwal, N.T. (2017). A Study on Kevin Lynch's Urban Design Elements: Precinct 9 East Putrajaya. International Transaction Journal of Engineering, Management, \& Applied Sciences \& Technologies. Volume 8, 153-167.

Lynch, K. (1960). The Image of the City. Massachusetts: The MIT Press.

Majlis Daerah Rembau (2021). Draf Rancangan Tempatan Daerah Rembau 2025 (Pengantian)

Moudon, A.V. (1997) Urban morphology as an emerging interdisciplinary fi eld. Urban Morphology, 1(1), pp. 3-10.

Peter Hall, Mark Tewdwr-Jones (2010). Urban and Regional Planning. 
Volume 6 Issue 26 (December 2021) PP. 262-273 DOI 10/35631/JTHEM.626024

Puteri Shireen J.K, Kamariah, K., Illyani I., and Zalina H. (2019). A Tropicalized Urban Design Framework From Morphological Patterns Of Pre-Colonial Maritime Centers Of The Malay World. Geoinformatica Polonica 18: 2019

RWall, E. and Waterman, T. (2009) Basics Landscape Architecture: Urban Design. Lausanne: AVA Publishing.

Stephan Marshall and Olgu Caliskan 2011, A Joint Framework for Urban Morphology and Design, Built Environment 37(4), December 2011 